\title{
A.P. Пестова
}

Институт русского языка им. В.В. Виноградова РАН

(Россия, Москва)

pestova2012@gmail.com

\section{ИМЕННОЕ УПРАВЛЕНИЕ В РУССКОЙ РАЗГОВОРНОЙ РЕЧИ И ЕГО ОТРАЖЕНИЕ В СЛОВАРЕ}

В статье рассматриваются особенности синтаксического управления у существительных в русской разговорной речи $(\mathrm{PP})$ и отражение этих особенностей в толковом словаре. Анализ осуществляется с учетом моделей управления, характерных для кодифицированного литературного языка (КЛЯ). Описывается три варианта несовпадения моделей управления в РР и в КЛЯ: 1) в КЛЯ слово употребляется без зависимых, а в РР с зависимыми (на примере слов паника и маразм); 2) в КЛЯ существительное употребляется с зависимыми, а в РР их не имеет (на примере существительных бутылка и вирус) и 3) слово имеет разные модели управления в КЛЯ и в РР (на примере слов мастер, проблема, бред и глаз). Реже всего из перечисленных вариантов встречается второй: когда в КЛЯ слово употребляется с управлением, а в РP не имеет управляемых конструкций. Более типичным для РР является разнообразие вариантов управления. Отмечено, что это, как правило, обусловлено спецификой семантики слова в разговорной речи, а также ее общими характеристиками: спонтанностью, непринужденностью и эллиптичностью.

Ключевые слова: стратификация лексики, разговорная речь, лексикография, толковый словарь, синтаксис, именное управление.

Синтаксическое управление - важная лингвистическая информация о слове. Однако в традиционных словарях русского языка оно представлено непоследовательно и фрагментарно, главным образом в немногочисленных иллюстративных примерах, не отражающих вариативность (часто существующую в рамках нормы) ${ }^{1}$. Трудность систематического описания управления обусловлена тем, что для

1 Так, Ю.А. Бельчиков и Г. Я. Солганик, рассматривая лексикографические издания различной направленности, отмечают, что словари с информацией о синтаксических связях слов - это «наименее разработанный в русской лексикографии тип словарей» [Бельчиков, Солганик 1997: 41]. 
большого числа слов управление определяется индивидуально, в словарном поряд$\mathrm{re}^{2}$. На синтаксическую сочетаемость слова влияет целый ряд факторов, в том числе семантические. Объектом данного исследования являются существительные, значение и, соответственно, управление которых обусловлено той подсистемой языка, к которой они относятся: к кодифицированному литературному языку (далее КЛЯ) или к разговорной речи (далее - РР).

Работа над «Толковым словарем русской разговорной речи» под руководством Л.П. Крысина (см. [ТСРР-1, ТСРР-2, ТСРР-3]), в частности над зоной SYNT словарной статьи, в которой помещаются сведения о синтаксических характеристиках слова, показывает, что использование слова в повседневном речевом общении может влиять на его синтаксическое поведение 3 .

Следует отметить, что существительные, используемые как в РР, так и в КЛЯ, могут иметь одинаковое управление. Так, слово выжимки имеет в КЛЯ значение «то, из чего выжат сок, остатки после выжимания сока, масла» [АТоС] и управляет беспредложным родительным падежом либо предложно-падежной конструкцией из чего-л.: выжимки винограда, выжимки из льна. В РР это слово используется еще и в значении «предельно краткое содержание чего-либо» [ТСРР-1] и имеет такую же модель управления: выжимки монографии, выжимки из выступления. Существительное монополия с семантикой «исключительное право государства, организации, фирмы и т. п. на производство, продажу чего-л. или на деятельность в какой-л. сфере общественной жизни» [БТС] управляет беспредложным родительным падежом и предложно-падежной конструкцией на что-л.: монополия предприятия на производство стали. В РР это слово с семантикой «об исключительном праве, преимуществе, первенстве кого-л. в какой-л. области» [БТС] имеет такую же сочетаемость: $B$ 1995-м закончилась столичная монополия на звание Чемпиона России. Имя первого немосковского чемпиона навеки осталось в истории российского футбола (Блоги, 2016).

В данной статье рассматриваются случаи, когда синтаксическое поведение в КЛЯ и в РР у одного и того же существительного различается. Такое расхождение возможно и в случае семантического различия слова в КЛЯ и РР, и в случае тождества или сходства значений.

Возможны три варианта такого расхождения.

\section{1. В КЛЯ слово употребляется без зависимых, а в РР имеет управляемые} конструкции. Рассмотрим в качестве примеров существительные паника и маразм.

В КЛЯ слово паника в значении «внезапный непреодолимый страх, сильное смятение, охватившее кого-л. (обычно сразу многих людей)» [БТС] используется без зависимых:

2 Хотя выделяются семантические разряды слов с однотипными синтаксическими свойствами [Апресян 1967: 118 и сл.]; [Ицкович 1968: 20]; [Апресян 1995: 545].

${ }^{3}$ См. также [Щерба 1957: 116], [Золотова 1973: 115-117], [Земская 1996: 13], [Гловинская 1996], [Крысин 2018]. 
Если бы поднялась паника - все бы друг друга передавили (М. Шишкин. Венерин волос).

В РР паника используется в близком значении «массовое волнение по поводу чего-л.» и встречается с конструкцией вокруг чего-л.:

Кому выгодна паника вокруг свиного гриппа? (Блоги, 2009).

Народ, похоже, устал от паники вокруг курса рубля (Блоги, 2014).

Еще один пример такого несовпадения - существительное маразм. В КЛЯ оно употребляется в значениях «состояние полного упадка психической и физической деятельности человека вследствие старости или длительной хронической болезни» [БТС] и используется без управляемых конструкций:

К кониу жизни Лида стала терять память, приговаривала, что склероз - самое удобное заболевание, с ним забываешь о других болячках и о маразме тоже (А. Иличевский. Медленный мальчик).

Управляемые конструкции появляются у этого слова в РР, где оно употребляется в переносном значении «о чем-л. абсурдном, крайне нелепом» [ТСРР-2017]. Это предложно-падежные конструкции с чем-л. и вокруг чего-л.:

Когда закончится маразм со штрафами за недобор газа, электричества? (Блоги, 2009).

В мае публиковал пост про маразм с установкой знаков платной парковки (Блоги, 2013).

При всем маразме вокруг игр наши спортсмены, в этой крайне сложной и нервозной ситуации, выступили вполне достойно (Форум, 2016).

Маразм вокруг темы глобального потепления не стихает (Блоги, 2018).

2. В КЛЯ слово употребляется с зависимыми, а в РР их не имеет. Проиллюстрируем это на примере существительных бутылка и вирус.

Слово бутылка в КЛЯ имеет значение «стеклянный сосуд для жидкостей, обычно цилиндрической формы, с узким продолговатым горлом, или пластиковый, пластмассовый и т. п. сосуд такой формы» [AТоC, т. 1] и может управлять предложно-падежными конструкциями для чего-л., под что-л., из-под чего-л. и с чем-л.: бутылка для молока, под масло, из-под вина, с бензином. В значении «мера количества чего-л., помещенного в такой сосуд» [Там же] это слово управляет беспредложным родительным падежом: бутылка воды.

В РР семантика этого слова сужается: оно употребляется в значении «об одной емкости спиртного (обычно водки)» [ТСРР-2014] и не имеет при себе зависимых:

Бутылку жена спрятала/ еле нашли// (Запись устной речи, 2010).

На пять мужиков три бутылки? Да ты что/ им и пяти-то мало! (Запись устной речи, 2011).

$B b l$, девки, наводите порядок, а я бегу за бутылкой (В. Пронин. Испанский гость).

Кроме того, в РР бутылка может обозначать спиртное вообще и в таком случае тоже употребляется без зависимых:

Рано тебе ещё с бутылкой дружить (Ф. Абрамов. Пелагея). 
Напьется, свалится пьяный, проспится и опять за бутылку. Так и пил, пока «Агдам» этот не кончился. Потом и «Саперави» выжсрал (О. Пернай. В одной организации...).

Существительное вирус в значении «мельчайший микроорганизм, возбудитель инфекционных заболеваний человека, животных и растений, размножающийся в живых клетках» [АТоС, т. 2] в КЛЯ обычно используется с беспредложным родительным падежом:

Рыжжй кот дикий и, возможно, является разносчиком вируса бешенства или других вредных заболеваний. (Наука и жизнь, 2008).

Такое же синтаксическое поведения и у слова вирус в переносном значении «о чём-л. негативном, обладающем способностью к быстрому распространению» [AToC]:

Вирус агрессии и недовольства летает от человека к человеку, стремительно размножаясь. (М. Петросян. Дом, в котором...)

В РР это слово употребляется в значении «вирусная инфекция» [ТСРР-2014] и используется без управления:

Я этой зимой таким вирусом переболела// Две недели пластом пролежала// (Запись устной речи, 2010).

Ребёнок болеет вирусом, четвёртый день температура (Блоги, 2015).

Следует отличать такие случаи отсутствия управления в РР от намеренного нарушения норм управления, которые говорящий может допускать в качестве языковой игры: Не вижу виновника// (опущено слово торжества): слово виновник в РР, как и в КЛЯ, требует после себя зависимого слова в родительном падеже, однако в приведенном примере говорящий его опускает для создания комического эффекта ${ }^{4}$.

3. Слово имеет разные модели управления в КЛЯ и в РР. В качестве примеров можно привести слова мастер, проблема, бред и глаз.

Одно из значений, в котором употребляется существительное мастер в КЛЯ, «человек, достигший большого умения, мастерства в работе, творчестве, деле» [БТС]. Оно управляет беспредложным родительным падежом и предложно-падежными конструкциями в чём-л. и по чему-л.:

У этого великого мастера живописи был незаурядный литературный талант (К. Чуковский. Репин - писатель).

Китайцьь, великие мастера в обращении с пустотой, знали три способа ее использования (А. Генис. Довлатов и окрестности).

Как показали раскопки усадьбы Олисея Гречина, в его иконописной мастерской работали не только живописиьь, но и мастера по производству серебряньх иконных окладов (Вестник РАН, 2004).

В РР слово мастер употребляется и в значении «искусный, ловкий в каком-л. деле человек» [БТС], и в значении «человек, имеющий склонность к чему-л., охотник до чего-л» [ТСРР-2], и помимо управления конструкцией на что-л.:

\footnotetext{
${ }^{4}$ Пример из [Капанадзе 2005: 116].
} 
- Придумай что-нибудь, Викусь. Ты же у нас мастер на выдумки (Г. Лавецкая. Между любовью и любовью),

может подчинять себе форму инфинитива (обычно вместе с его зависимыми), и это яркое отличие от употребления слова мастер в КЛЯ:

- Но ты понимаешь/ в принциие эта наша привычка всем всегда советовать... Вот Вика у нас/ большой мастер давать советы// (К/ф «Частная жизнь», 1982).

- Ты его слушай больше. Андрюша мастер сказки рассказывать (А. Берсенева. Полет над разлукой).

- Очень даже себе на уме, старый мухомор. Мастер наводить тень на плетень (С. Гандлевский. НРЗБ).

Существительное проблема в КЛЯ имеет значение «сложный вопрос, нуждающийся в специальном исследовании; задача, не имеющая пока решения» [БТС] и употребляется с беспредложным родительным падежом:

То, чем занимаются братья Сальниковы, - путь к решению острейших проблем воспитания и образования (Сельская новь, 16.09.2003).

В РР во второй половине ХХ в. у слова проблема появилось размытое значение «о чём-л. трудновыполнимом, трудноосуществимом; вообще какая-л. трудность, неприятность» [ТСРР-3], — возможно, под влиянием английских оборотов со словом problem. При этом оно может управлять конструкциями у кого с кем-чем-л., в чём-л:

У папы опять проблемы со спиной// Поясница отказывает// (Запись устной речи, 2016).

У меня такая же проблема с сыном была. Война была со школой насмерть у меня. Учителям нынче на детей плевать (Блоги, 2016).

Нужно как можно скорее... пойти в банк и уведомить его о грядущчих проблемах в выплатах (Блоги, 2014).

Кроме того, в публицистических текстах встречается управление вокруг когочего-л., при этом существительное проблема всегда имеет форму множественного числа:

Проблемы вокруг проживания иногородних студентов в общагах из года в год одни и те же: на всех не хватает мест, ужасные бытовые условия, наглая администрация (Комсомольская правда, 14.08.2006).

Разрубить узел проблем вокруг Милошевича будет далеко не просто, так как конституцчия Сербии не допускает выдачу сербских граждан иностранным судам (Труд-7, 16.01.2001).

Слово бред в КЛЯ имеет значение «бессознательное состояние человека, сопровождающееся галлюцинациями, бессвязной речью и т. п.», а также сама такая речь [AТоС, т. 1]. Оно управляет беспредложным родительным падежом: бред кого-л.:

- Ну зачем же обращать столько внимания на бред больного? (Э. Радзинский. Княжна Тараканова).

В значении «мания человека, состоящая в ложном представлении, которое определяет его поведение» [AC] бред может также управлять словами, обозначающими это ложное представление: 
Он достал книжку о нравах и привычках душевнобольных, и после долгих споров из всех навязчивых идей был выбран бред величия (И. Ильф, Е. Петров. Золотой теленок).

Любовь порождает бред, чащзе всего бред ревности (Знание - сила, 1997).

В РР значение более широкое: «о чём-л. бессмысленном, нелепом, неправдоподобном» [ТСРР-1]. Здесь возможно несколько вариантов управления. Первый беспредложным родительным падежом (кого-чего-л.):

Перечитала этот бред гимназистки, и вдруг стало так очевидно, что ничего у нас не будет, что ты никогда не уйдешь от нее ко мне (М. Шишкин. Венерин волос).

Наверное, весь этот бред рекламы, обещающей нам элитные квартиры в элитных домах... так и будет продолжаться (Блоги, 2013).

Второй вариант, который употребляется в РР, - предложно-падежная конструкция о ком-чём-л.:

Я не хочу повторять тот бред о пьяных русских, коим только кухонньй нож можно доверить (Блоги, 2012).

Я-то уж было поверила в этот бред о сказочном наследстве (М. Милованов. Естественный отбор).

Встречается, кроме того, управление вокруг кого-чего-л.:

Я имею в виду... фанатский бред вокруг актёра... Одна роль - и мир (девушек) сомел с ума (Форум, 2011).

Помните бред вокруг генетики в 50-60 годы? Мол, если привносить некие изменения в тело животного физически, то они закрепятся на генном уровне (Блоги, 2002).

И наконец, в РР слово бред может управлять конструкцией с чем-л.:

Что за бред с налогами с продажи авто? (Блоги, 2010).

Что за бред с телефоном? При включении телефона идёт надпись МТС и телефон перезагружается, так бесконечно (Блоги, 2015).

Существительное глаз в одном из своих значений «особая способность ви́дения, присущая человеку благодаря тому или иному занятию, профессии и т. п.» [MАС] в КЛЯ управляет беспредложным родительным падежом:

Описание методики исследования было намеренно сделано с грубыми, сразу заметныли глазу специалиста ошибками (Знание - сила, 2014).

Метель гнала и гнала по степи снежные вихри, и утром даже намётанный глаз охотника не приметил бы в ней каких-либо следов (Г. Гусаченко. Тигровый перевал).

В РР глаз в этом значении обычно употребляется с оценочным прилагательным в конструкции кого-л. на кого-что-л.:

А у него был острейший, звериный слух и глаз на оттенки и интонацию (Д. Рубина. Белая голубка Кордовы);

У нее феноменальный глаз на всё, начиная от одежды, образа в цуелом до мельчайшей детали в пространстве (Мурманский вестник, 14.03.2015).

Только я частенько его видел с очень даже приятными дамами. Глаз у него хороший на женщци, ничего не скажешь (Блоги, 2012). 
Рассмотренный материал позволяет нам сделать следующие выводы.

Во-первых, особенности управления существительных в РР обусловлены ее общими характеристиками: спонтанностью, непринужденностью и эллиптичностью. Такие словосочетания, как проблемы вокруг проживания, бред с налогами, бумага на тебя - это эллиптичные конструкции, в которых обозначаются целые ситуации, вне контекста не всегда понятные, но возможные в условиях непринужденного общения.

Во-вторых, обычно разница в управлении в РР и КЛЯ связана со спецификой семантики слова в РР. Однако несовпадение форм управляемых конструкций возможно и при одинаковом или близком значении слова. Это отчетливо видно на примере со словом глаз.

В-третьих, как показывает рассмотренный материал, самый редкий вариант несовпадения управления - когда в КЛЯ существительное имеет при себе управляемые синтаксические конструкции, а в РР то же слово употребляется без зависимых. Более типична обратная ситуация. А в случаях, когда слово имеет различные варианты управления в КЛЯ и в РР, в последней вариантов синтаксического управления обычно больше, чем в КЛЯ.

\section{Литература}

Апресян Ю.Д. Избранные труды. Т ІІ. Интегральное описание языка и системная лексикография. М. : Языки русской культуры, 1995. 767 с.

Апресян Ю. Д. Экспериментальное исследование семантики русского глагола. М.: Наука, 1967. 252 с.

АС - Активный словарь русского языка. Т. 1: А-Б / Отв. ред. академик Ю. Д. Апресян. М.: Языки славянской культуры, 2014. 408 с.

АТоС - Академический толковый словарь русского языка. Т. 1, 2 / Отв. ред. Л.П. Крысин. М.: Издательский Дом ЯСК, 2016.

Бельчиков Ю.А., Солганик Г.Я. О лексикографических изданиях адресной направленности // Облик слова. Сборник статей памяти Дмитрия Николаевича Шмелёва / Отв. ред. Л. П. Крысин. М.: Институт русского языка РАН, 1997. С. 41-47.

БТС - Большой толковый словарь русского языка / Под ред. С. А. Кузнецова. СПб., 2000. 1535 с.

Гловинская М.Я. Активные процессы в грамматике (на материале инноваций и массовых языковых ошибок) // Русский язык конца ХХ столетия (1985-1995). М.: Языки русской культуры, 1996. С. 237-304.

Земская Е.А. Введение // Русский язык конца ХХ столетия (1985-1995). М.: Языки русской культуры, 1996. С. 9-31.

Золотова Г.А. Очерк функционального синтаксиса русского языка. М.: Наука, 1973. $351 \mathrm{c}$.

Ииякович В. А. Языковая норма. М.: Просвещение, 1968. 92 с.

Капанадзе Л. А. Голоса и смыслы. Избранные работы по русскому языку / Отв. ред. Л.П. Крысин. М., Институт русс. яз. им. В. В. Виноградова РАН, 2005. 333 с. 
Крысин Л.П. Коммуникативно актуальные смыслы и их лексико-грамматическое выражение в повседневной речи // Взаимодействие лексики и грамматики. Тезисы докладов международной конференции Двенадцатые Шмелевские чтения (24-26 февраля 2018 г.). М., 2018. С. 45-46.

МАС - Словарь русского языка: В 4-х т. / Под ред. А.П. Евгеньевой. М.: Рус. яз., 1999.

ТСРР-1 - Толковый словарь русской разговорной речи. Вып. 1, А - И / Отв. ред. Л.П. Крысин. М.: Языки славянской культуры, 2014. 776 с.

ТСРР-2 - Толковый словарь русской разговорной речи. Вып. 2, К - О / Отв. ред. Л.П. Крысин. М.: Языки славянской культуры, 2017. 864.

ТСРР-3 - Толковый словарь русской разговорной речи. Вып. 3, П - Р / Отв. ред. Л.П. Крысин. М.: Языки славянской культуры, 2019. 824 с.

Щерба Л.В. Современный русский литературный язык // Избранные работы по русскому языку. М.: Учпедгиз, 1957. С. 110-129.

\author{
A. R. Pestova \\ V.V. Vinogradov Russian Language Institute (Russian Academy of Sciences) \\ (Moscow, Russia) \\ pestova2012@gmail.com
}

\title{
NOUN GOVERNMENT IN RUSSIAN EVERYDAY SPEECH AND ITS REPRESENTATION IN THE DICTIONARY
}

This paper deals with specific features of the noun government in the Russian everyday speech and its representation in the explanatory dictionary. The analysis considers the models of government, typical for codificated standard language. Three variants of the difference between the government in the colloquial speech and the standard language are described: 1) the noun is used without any governed words in the standard language and with the governed words in the everyday speech (nouns panika 'panic' and marazm 'dementia' are given as examples), 2) the word is used with the governed words in the standard language and without any governed words in the colloquial speech (nouns butylka 'bottle' and virus 'virus'), and 3) the noun has different models of government in the standard language and in the colloquial speech (nouns master 'master', problema 'problem', bred 'delirium' and glaz 'eye'). The second variant is the least common. The variety of the models of government is more typical for the Russian colloquial speech. It's mentioned, that this feature is connected with the specifical semantics of the word in the everyday speech as well as its general characteristics: spontaneity, naturalness and ellipticity.

Keywords: stratification of the vocabulary, everyday speech, lexicography, explanatory dictionary, syntax, noun government. 


\section{References}

Akademicheskij tolkovyj slovar' russkogo yazyka. T. 1, 2 [Academic explanatory dictionary of the Russian language] / L.P. Krysin, ed. Moscow: Izdatel'skii Dom YaSK Publ., 2016.

Aktivnyj slovar' russkogo jazyka. T. 1: A-B [Active dictionary of Russian. Vol. 1: $A-B] /$ Yu. D. Apresyan, ed. Moscow, 2014. 408 p.

Apresyan Yu. D. Eksperimental'noe issledovanie semantiki russkogo glagola. [Experimental research in the semantics of the Russian verb]. Moscow: Nauka Publ., 1967. 252 p.

Apresyan Yu. D. Izbrannye trudy. T. II: Integral'noe opisanie yazyka i sistemnaya leksikografiya. [Selected works. Vol. II: Integrated description of language and systematic lexicography]. Moscow: Yazyki Russkoi Kul'tury Publ., 1995. 767 p.

Bel'chikov Yu. A., Solganik G. Ya. [About target-focused lexicographic editions] // Oblik slova. Sbornik statej pamyati Dmitriya Nikolaevicha Shmelyova [Image of the word. Collected papers in memory of Dmitrii Nikolaevich Shmelyov] / L. P. Krysin, ed. Moscow: Institut russkogo yazyka RAN Publ., 1997, pp. 41-47. (In Russ.)

Glovinskaya M. Ya. [Active processes in grammar (a case study of innovations and mass speech errors] // Russkij yazyk konca XX stoletiya (1985-1995) [Russian language in the end of the $20^{\text {th }}$ century (1985-1995)]. Moscow: Yazyki Russkoi Kul'tury Publ., 1996, pp. 237-304.

Ickovich V.A. Yazykovaya norma [Language norm]. Moscow: Prosveshchenie Publ., 1968. $92 \mathrm{p}$.

Kapanadze L. A. Golosa i smysly. Izbrannye raboty po russkomu yazyku [Voices and senses. Selected works about the Russian language] / L. P. Krysin, ed. Moscow: Institut russ. yaz. im. V.V. Vinogradova RAN Publ., 2005. 333 p.

Krysin L.P. [Communicative actual senses and their lexical-grammar expression in everyday speech] // Vzaimodejstvie leksiki i grammatiki. Tezisy dokladov mezhdunarodnoj konferencii Dvenadcatye Shmelevskie chteniya (24-26 fevralya 2018 g.) [The interaction between lexicon and grammar. Abstracts of the International scholarly conference The Twelfth Shmelev readings (February, 24-26, 2018). Moscow, 2018, pp. 45-46. (In Russ.)

Shcherba L. V. [Modern Russian standard language] // Izbrannye raboty po russkomu yazyku [Selected works about the Russian language]. Moscow: Uchpedgiz Publ., 1957, pp. 110-129.

Slovar' russkogo yazyka: $V$ 4- $h t$. [Dictionary of the Russian language: in 4 vol.] / A. P. Evgen'eva, ed. Moscow: Rus. yaz. Publ., 1999.

Tolkovyj slovar' russkoj razgovornoj rechi. Vyp. 1, 2, 3. [Explanatory dictionary of the Russian everyday speech. Vol. 1, 2, 3] / L.P. Krysin, ed. Moscow: Yazyki slavyanskoi kul'tury Publ., 2014, 2017, 2019.

Zemskaya E. A. Introduction // Russkij yazyk konca XX stoletiya (1985-1995) [Russian language in the end of the $20^{\text {th }}$ century (1985-1995)]. Moscow: Yazyki Russkoi Kul'tury, 1996, pp. 9-31.

Zolotova G. A. Ocherk funktsional'nogo sintaksisa russkogo yazyka [Essay on functional syntax of the Russian language]. Moscow: Nauka Publ., 1973. 351 p. 